озглянуто суч сну кл сифік цію земельних угідь т їхнє зн чення в житті людини. озкрито принципи т основні підходи у дослідженні землекористув ння. пропонов но у системі кл сифік ційних к тегорій землекористув ння виділяти типи і форми землекористув ння.

лючові слов : землекористув ння, принципи, кл сифік ційні к тегорії, типи і форми землекористув ння.

роцес ст новлення т розвитку людського суспільств нерозривно пов'яз ний із використ нням природних ресурсів, отже, процес природокористув ння є невід'ємною умовою існув ння людини. ині однією з центр льних проблем, як визн ч є сьогодення і м йбутнє людської цивіліз ції, є орг ніз ція р ціон льного природокористув ння, яке передб ч є виявлення певних гр ничнодопустимих ст нів природного середовищ т розробки стр тегії поведінки суспільств для з безпечення под льшого розвитку людств . структурі природно-ресурсного потенці лу кр їни н йбільшу ч стку $з$ йм ють земельні ресурси, які зумовлюють існув ння т використ ння всіх інших видів природних ресурсів, отже, будь-які види природокористув ння передусім треб розгляд ти як землекористув ння. истем землекористув ння в різних регіон х н шої держ ви сформув л сь під впливом природних, історичних, етнокультурних, соці льноекономічних чинників, які зумовили поєдн ння різних н прямів використ ння земельного фонду т формув ння певного ст ну екологічної ситу ції.

умови посилення нтропогенного н в нт ження н земельні ресурси, які виконують функції предмет пр ці і з собу виробництв в сільському і лісовому господ рстві, природного ресурсу і носія корисних коп лин, просторового б зису всієї сукупності форм і видів суспільної діяльності, територі льної основи держ вності і н ціон льного с мовизн чення, особливо гостро пост є пит ння р ціон льного землекористув ння. ціон льним ув ж ють т ке використ ння земель, з якого поряд із виробництвом економічно доцільної кількості продукції зберіг ється екологічн рівнов г всіх природних чинників. ізні суспільні інтереси щодо р ціон льного, ефективного використ ння землі виявляються в двох спект х, у першому р ціон льність визн чен гр ничнодопустимими нтропогенними н в нт женнями н довкілля і земельні ресурси, у другому р ціон льним ув ж ють стійке, низьковитр тне і високопродуктивне землекористув ння, результ тів якого досяг ють з вдяки н йповнішій відповідності суспільному споживчому попиту, витр ти м ють стійку тенденцію до зниження вн слідок ктивного освоєння досягнень н уково-технічного прогресу і соці льної мотив ції до високопродуктивної пр ці. цьому р зі суспільство з цік влене в тому, щоб висок продуктивність освоєння т використ ння землі поєднув л сь з м ксим льним збереженням і примноженням її корисних вл стивостей [8].

(C) ньків ., 2011 
жливе зн чення земельних ресурсів у суспільному виробництві т функціонув нні біосфери зумовлює зн чний інтерес до дослідження пр вових, просторових, економічних, екологічних п р метрів землекористув ння широким колом н уковців (екологів, економістів, землевпорядників, геогр фів т ін.). роте систем кл сифік ційних к тегорій, які використовують під ч с дослідження особливостей використ ння землі, $\epsilon$ розрізненою т недоскон лою. р вові спекти землекористув ння обумовлені емельним кодексом кр їни т низкою норм тивно-пр вових документів. емельний кодекс регл ментує поділ земель кр їни т ї̈ дміністр тивно-територі льних утворень н дев'ять к тегорій з основним цільовим призн ченням: землі сільськогоспод рського призн чення, житлової т гром дської з будови, природно-з повідного т іншого природоохоронного призн чення, оздоровчого призн чення, рекре ційного призн чення, лісового т водного фонду, промисловості, тр нспорту, зв'язку, енергетики, оборони т іншого призн чення [1]. кож з конод вство кр їни чітко регл ментує поділ земель 3 форм ми вл сності (прив тн, комун льн, держ вн ) т вид ми користув ння (постійне користув ння т оренд ), визн ч є перелік к тегорій землевл сників і землекористув чів.

истем землекористув ння в кр їні предст влен сукупністю земельних ділянок, що м ють різном нітні природно-історичні вл стивості, різняться 3 х р ктером використ ння т н леж ть до різних земельних угідь. тже, основним елементом обліку кількості земель у р зі ведення держ вного земельного к д стру є земельні угіддя ділянки, які систем тично використовують для певних цілей і які відрізняються з природно-історичними озн к ми. оловною озн кою, що взят з основу розділення окремих видів угідь, є перев жний н прям використ ння земель. ля кількісного обліку земель н к зом ержст нд рту кр їни введено в дію кл сифік цію земельних угідь т видів економічної діяльності, як передб ч є виділення т ких к тегорій: сільськогоспод рські землі, ліси т інші лісовкриті площі, з будов ні землі, відкриті з болочені землі, сухі відкриті землі з особливим рослинним покривом, відкриті землі без рослинного покриву бо з незн чним рослинним покривом і води $[4,6]$. перев жній більшості н укових досліджень використовують с ме цю кл сифік цію, як д є змогу визн чити особливості розподілу земельного фонду 3 к тегоріями угідь і містить достовірну систему кількісних відомостей (форм 6-зем, 6 -зем, 6б-зем). роте використ ння земельнок д стрової кл сифік ції д є змогу визн чити розподіл земель 3 угіддями, не виявити перев жні к тегорії землекористув ння. слуговує н ув гу спроб впорядкув ння понятійно-термінологічної системи землекористув ння, розроблен сіяником, який 3 пропонув в використовув ти основний термін “форм землекористув ння”, який в економічній геогр фії співвідноситься із земельними угіддями, в л ндш фтозн встві - 3 нтропогенними угіддями [2, 3]. роте цей термін з стосовують до різнорівневих н прямів використ ння земельного фонду. икорист ння розрізнених кл сифік ційних к тегорій у ході дослідження землекористув ння призводить до хибного тр ктув ння отрим них результ тів. ому сьогодні кту льною проблемою є розробк єдиних кл сифік ційних к тегорій т підходів у дослідженні особливостей землекористув ння.

сновним об'єктом землекористув ння є земля, як м є унік льне, ключове зн чення в усій системі підприємницької діяльності людей і с мого її життя. емля м є особливу цінність для всього людського суспільств , оскільки є єдиним місцем прожив ння всіх н родів, основним природним чинником у будь-якій сфері бізнесу, прямим бо непрямим уч сником виробництв всіх тов рів і бл г. ьогодні існує б г тозн чність тр ктув ння термін земля - це вся пл нет , як існує нез лежно від волі людей т ви- 
конує в жливу екологічну функцію. кож землю тр ктують як грунт, верхній родючий ш р пл нети, що є об'єктом господ рюв ння т відобр ж є економічні відносини. дноч сно землю розгляд ють як територію держ ви, вон виконує політичну функцію [8]. ервинним об'єктом будь-якого землекористув ння є земельн ділянк як ч стин земної поверхні з уст новленими меж ми, певним місцем розт шув ння т визн ченими щодо неї пр в ми.

ослідження проблем ефективного i p ціон льного землекористув ння є міждисциплін рним н прямом, оскільки земельні ресурси є основою будь-якого виду господ рської діяльності. рг ніз ція р ціон льного використ ння земельних ресурсів повинн вр ховув ти зон льні, регіон льні т лок льні особливості конкретних територій. оряд з цим у землекористув нні є певні з кономірності, без ур хув ння яких неможливо досягти позитивних результ тів. методологічного погляду вкр й в жливим є формув ння основних принципів р ціон льного землекористув ння, якими необхідно керув тись у кожному конкретному вип дку. суч сному ет пі принципи р ціон льного землекористув ння поділяють н 3 г льні т опер ційні. ід 3 г льними розуміють т кі принципи, що х р ктеризують основи под льшої побудови теорії т формув ння предметних понять, $є$ визн ч льними для конкретних н укових н прямів, $є$ основою побудови з г льних методичних підходів. кими принцип ми у землекористув нні можн вв ж ти:

) єдність використ ння, поліпшення т охорони земельних ресурсів;

б) ретельне вр хув ння ст ну природних ресурсів т умов природного середовищ ;

в) усебічне вр хув ння з конів природи в р зі орг ніз ції землекористув ння;

г) інтегр ція екологічного т економічного підходу до орг ніз ції використ ння земель у єдиний еколого-економічний підхід;

ж) збереження високої ефективності використ ння земель [5].

пер ційні принципи р ціон льного використ ння земель визн ч ють основний зміст окремих процедур і системи з ходів щодо орг ніз ції землекористув ння, т кож основні вимоги до шляхів і методів їх проведення. ому опер ційні принципи доцільно розробляти для кожного типу землекористув ння.

емлекористув ння - це порядок, умови і форми експлу т ції земель [7]. жливе т нез мінне зн чення землі у різних вид х господ рської діяльності зумовлює досить широкий спектр підходів до дослідження землекористув ння територі льних (просторових), пр вових, економічних, екологічних (рис. 1).

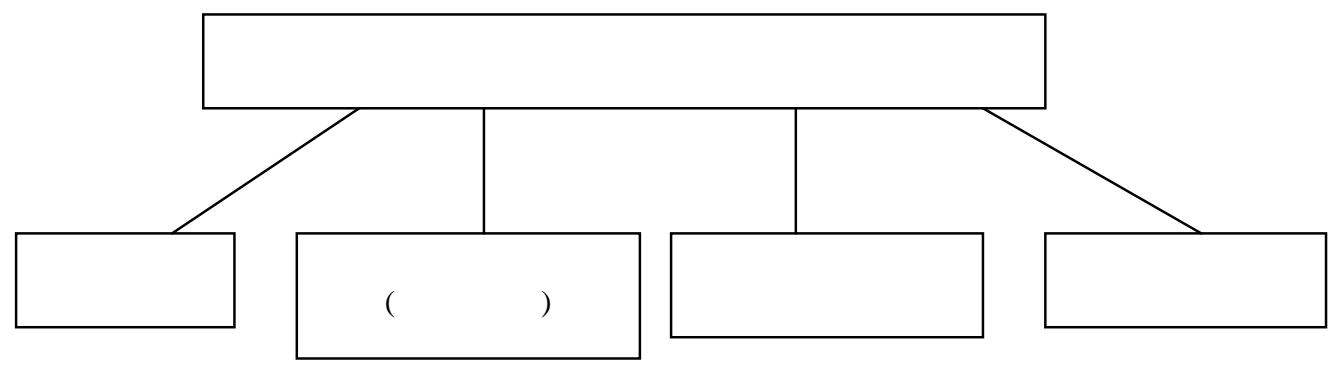

ис. 1. ідходи до дослідження землекористув ння. 
ериторі льно землекористув ння розгляд ють як одну чи декільк земельних ділянок, що виділені н місцевості т які систем тично використовують бо можуть використовув ти в різних вид х господ рської діяльності. сновними спект ми територі льного землекористув ння є: місце розт шув ння, площ , розміри і конфігур ція, скл д угідь т видів економічної діяльності, рельєф місцевості, х р ктеристик грунтових, геобот нічних, гідрологічних умов.

пр вових позицій землекористув ння розгляд ють як обумовлені з коном види, форми і порядок використ ння землі у відповідних меж х. р вові підходи д ють змогу визн чити особливості розподілу земель 3 форм ми вл сності, вид ми користув ння, к тегоріями землевл сників і землекористув чів, виявити спектр обмежень землекористув ння.

економічному спекті землекористув ння тр ктують як з сіб виробництв і сукупність пов'яз них із землею інших з собів виробництв (будівель, споруд т ін.), що зумовлюють іï використ ння в певній г лузі господ рств . сновними п р метр ми землекористув ння в економічному підході $\epsilon$ відповідність розмірів землекористув ння певному виду діяльності, н явність трудових, м тері льно-технічних і фін нсових ресурсів, відповідність скл ду угідь виробничому н пряму підприємств , $з$ безпеченість землекористув ння з соб ми виробництв . ожен тип і форм землекористув ння м ють свої специфічні економічні пок зники, проте н йбільш уз г льненим є чистий дохід з одиниці площі.

кологічний підхід передб ч є вр хув ння екологічних функцій, що виконують земельні ресурси, т грунтується н розр хунку екологічної ситу ції в меж х об’єкт дослідження н підст ві низки пок зників (співвідношення дест білізув льних т екологост білізув льних угідь, коефіцієнт нтропогенного перетворення т ін.), які вр ховують н слідки різних типів і форм землекористув ння.

ході еколого-геогр фічних досліджень землекористув ння треб розгляд ти як н прям природокористув ння поряд із водокористув нням, н др користув нням, біотокористув нням, повітрокористув нням, одн к обов'язково потрібно вр ховув ти, що с ме землекористув ння є основою усіх інших н прямів природокористув ння. ля виділення кл сифік ційних к тегорій землекористув ння в р зі проведення еколого-геогр фічних досліджень доцільно виділити дв рівні: типи, в їхніх меж х - форми землекористув ння (рис. 2). еред типів землекористув ння треб виділити: сільськогоспод рське, лісогоспод рське, селітебне, водогоспод рське, природоохоронне, рекреційне, оздоровче.

ільськогоспод рське землекористув ння - це тип використ ння земельних ділянок для виробництв сільськогоспод рської продукції, ведення сільськогоспод рської н уково-дослідної т н вч льної діяльності, розміщення відповідної виробничої інфр структури. сновними форм ми сільськогоспод рського землекористув ння є зерновотехнічн (рілля, перелоги, б г торічні н с дження), кормов (сінож ті, п совищ ) т господ рськ (землі під господ рськими будівлями і двор ми, шлях ми і прогон ми, землі, які перебув ють у ст дії відновлення родючості т тимч сової консерв ції, з бруднені сільськогоспод рські угіддя).

ісогоспод рське землекористув ння - це тип використ ння земельних ділянок, що вкриті лісовою рослинністю т не вкриті лісовою рослинністю, лісогоспод рськими підприємств ми, гром дян ми кр їни з метою з безпечення екологічних, економічних, соці льних т інших потреб суспільств у лісових ресурс х (деревних, технічних, 
емлекористув ння

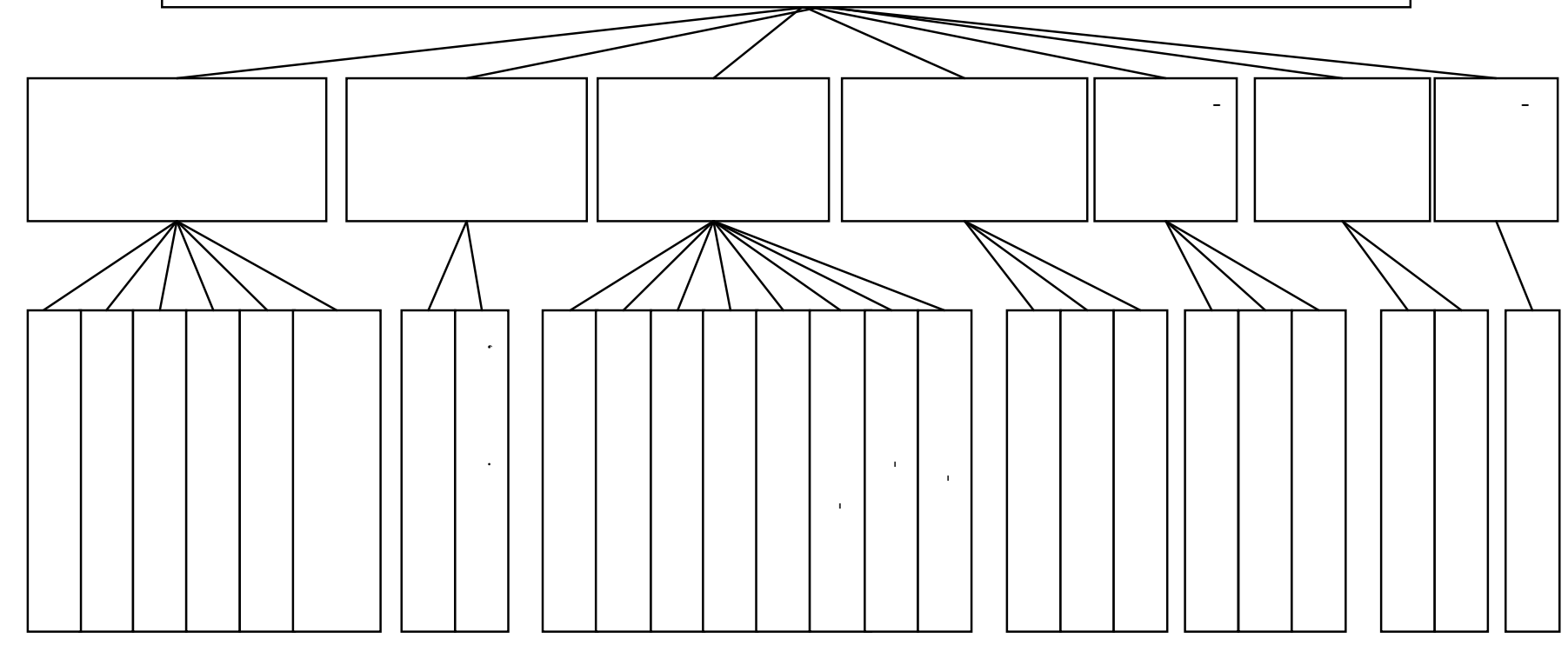

ис. 2. л сифік ційні к тегорії землекористув ння. 
лік рських і корисних вл стивостях лісів). сновними форм ми лісогоспод рського землекористув ння є експлу т ційн, грунтоз хисн, водоз хисн, рекре ційн .

одогоспод рське землекористув ння - це тип використ ння земельних ділянок, що 3 йняті морями, річк ми, озер ми, водосховищ ми, болот ми, остров ми, прибережними з хисними смуг ми вздовж водних об'єктів, гідротехнічними, водогоспод рськими споруд ми т к н л ми, береговими смуг ми водних шляхів, з метою р ціон льного використ ння вод для потреб н селення і г лузей економіки, відтворення водних ресурсів, охорони вод від з бруднення, з смічення т висн ження. орм ми водогоспод рського землекористув ння є експлу т ційн , гідротехнічн , рекре ційн .

риродоохоронне землекористув ння - це тип використ ння земельних ділянок, які з йняті природними територіями (природні з повідники, н ціон льні природні п рки, біосферні з повідники, регіон льні л ндш фтні п рки, з к зники, п м'ятки природи, з повідні урочищ ), штучно створеними об'єкТ ми (бот нічні с ди, дендрологічні п рки, зоологічні п рки, п рки-П м'ятки с дово-п ркового мистецтв ), які м ють особливу природоохоронну, екологічну, н укову, естетичну, рекре ційну цінність; грунто3 хисними, водоз хисними об'єкт ми і споруд ми з метою збереження унік льних л ндш фтів т недопущення погіршення корисних вл стивостей інших природних ресурсів. сновними форм ми природоохоронного землекористув ння є природоз повідн , грунтоз хисн , водоз хисн .

елітебне землекористув ння - це тип використ ння земельних ділянок, з йнятих житловою з будовою, гром дськими будівлями і споруд ми, основними, підсобними і допоміжними будівлями і споруд ми промислових, гірничодобувних, тр нспортних т інших підприємств, їхніми під'їзними шлях ми, інженерними мереж ми, дміністр тивно-побутовими будівлями 3 метою н йбільш повного з доволення потреб н селення в н лежних умов х прожив ння т здійснення різном нітних видів господ рської діяльності. сновними форм ми т кого землекористув ння є житлов , промислов , комерційн , гром дськ , тр нспортн , технічно-інфр структурн , військово-технічн , історикокультурн .

екре ційне землекористув ння - це тип землекористув ння, основною метою якого є створення сприятливих умов для відпочинку н селення. меж х цього типу землекористув ння доцільно виділити ктивну (земельні ділянки зелених н с джень н селених пунктів, н вч льно-туристичних і екологічних стежок, м рков них тр с) т ст ціон рну (території будинків відпочинку, туристичних 6 з, кемпінгів, ст ціон рних і н метових туристично-оздоровчих т борів, дитячих і спортивних т борів т ін.) форми.

здоровче землекористув ння - це тип використ ння земельних ділянок, основною метою якого є профіл ктик 3 хворюв нь т лікув ння людей. оздоровчому землекористув нні виділяють тільки ст ціон рну форму (земельні ділянки с н торії, лікув льних курортів т ін.).

тже, ст новлення людського суспільств нерозривно пов'яз но із використ нням земельних ресурсів, які є основою функціонув ння всіх видів господ рської діяльності, що зумовлює необхідність дослідження особливостей землекористув ння в окремих природних і дміністр тивних утвореннях. пропонов ні принципи, підходи т кл сифік ційні к тегорії д ють змогу подол ти однобічність у вивченні землекористув ння, обгрунтув ти екологобезпечне поєдн ння різних типів і форм землекористув ння. 3н чен систем пок зників у кожному н пряму дослідження землекористув ння допоможе викон ти глибший н ліз суч сного ст ну т 3 пропонув ти з ходи щодо його оптиміз ції в еколого-економічному спекті. 
1. емельний кодекс кр їни : меняр. . : дісей, 2002.600 с.

2. сіяник . . тегорії землекористув ння в понятійно-термінологічній системі природокористув ння / . . сіяник, . . сіяник // уч сні проблеми зб л нсов ного природокористув ння. м'янець- одільський: ид-во одільського держ. гр р.-техн. ун-ту, 2009. . 48-50.

3. сіяник. . колого-геогр фічний н ліз т оцінк використ ння земель (н м тері л х мельницької обл сті) / . . сіяник : втореф. дис. н здобуття н ук. ступеня к нд. геогр. н ук. ьвів, 2010. $20 \mathrm{c}$.

4. г зинщиков . . емельний к д стр: ідручник / . . г зинщиков. ьвів : віт, 1991. $452 \mathrm{c}$.

5. рг ніз ція сільськогоспод рського використ ння земель н л ндш фтно-екологічній основі / ред. . . зьмір . ьвів : ,2009. 254 с.

6. ньків . . емельні ресурси: вч льний посібник / . . ньків. ьвів : ид. центр імені в н р нк, 2008. 272 с.

7. еймерс . . риродопользов ние. лов рь-спр вочник / . . еймерс. . : ысль, 1990. $638 \mathrm{c}$.

8. ретьяк . . емельн політик т земельні відносини, соці льно-економічні і духовні спекти розвитку / . . ретьяк, . . руг к. . : « нститут гр рної економіки», 2007.186 с.

\title{
THE SYSTEM OF CLASSIFIED OF THE LAND USE
}

\section{Z. Pan'kiv}

Ivan Franko National University of Lviv, . Doroshenko St., 41, UA - 79000 Lviv, Ukraine

The modern classification of the objects of area of economic significance and their importance in our life were examined. It was discovered the principles and the main approaches in the investigation of the land use. Also it was suggested to distinguish types and forms into the system of classified categories of the land use.

Key words: land use; principles; classified categories; types and forms of the land use.

\author{
. НЬКИВ \\ ввовский н цион льный университет имени в н рнко, \\ ул. . орошенко, 41, г. ьвов, 79000, кр ин
}

ро н лизиров но современную кл ссифик цию земельных угодий и их зн чение в жизни человек . скрыто принципы и основные подходы в исследов нии землепользов ния. редложено в системе кл ссифик ционных к тегорий выделять типы и формы землепользов ния.

лючевые слов : землепользов ние, принципы, кл ссифик ционные к тегории, типы и формы землепользов ния.

т ття н дійшл до редколегії 02.11.2010 рийнят до друку 16.11.2010 